\title{
NOTES ON VELIGERS OF JAPANESE OPISTHOBRANCHS (1)
}

AUTHOR(S):

Hamatani, Iwao

\section{CITATION:}

Hamatani, Iwao. NOTES ON VELIGERS OF JAPANESE

OPISTHOBRANCHS (1). PUBLICATIONS OF THE SETO MARINE

BIOLOGICAL LABORATORY 1960, 8(1): 59-70

\section{ISSUE DATE:}

1960-05-30

URL:

http://hdl.handle.net/2433/174701

RIGHT: 


\title{
NOTES ON VELIGERS OF JAPANESE OPISTHOBRANCHS (1)
}

\author{
IWAO HAMATANI \\ Sennan Senior High School, Tarui, Osaka
}

With 8 Text-figures

Since the publication of previous papers (BABA and Hamatani, 1952; BabA, HAMATANI and Hisai, 1956), I have continued to work on the biology of Japanese opisthobranchs especially on the morphology of their veligers, in a hope to make it possible to identify these veligers occurring in plankton samples. This is the first report of the series and includes the descriptions about the following four species: Stiliger (Stiliger) boodleae BABA, Elysia (Elysia) hamatanii BABA, Gymnodoris bicolor (AlDER and HANCOCK), and Catriona bicolor (BERGH). Figures in the paper were all made on living specimens by using ABBE's drawing apparatus.

Before going further, my hearty thanks are due to Prof. Kikutaro BABA of Osaka Gakugei University for his suggestions given during the present study and also to Dr. Takasi Tokioka and Dr. Huzio UTinomi of Seto Marine Biological Laboratory for their generous helps and useful advices given during my stay at the Laboratory.

\section{Stiliger (Stiliger) boodleae BABA}

(Figs. 1-3)

BABA and HAMATANI, 1952, pp. 87-89, fig. 1.

This species can be found in considerable numbers on the shore near Seto Marine Biological Laboratory. It varies greatly in length as shown in Fig. 1. The egg-laying takes place very frequently in the laboratory culture. Even the specimens smaller than $3 \mathrm{~mm}$ in length may spawn; their egg-bands are naturally small measuring only 1 to $1.6 \mathrm{~mm}$ in length (Fig. 2, A and B). The normal egg-masses are, however, much larger and more elongated and slightly curved (see BabA and Hamatani, 1952); sometimes they make up 1 to 2 turns in the

1) Contributions from the Seto Marine Biological Laboratory, No. 346.

2) A part of the studies supported by the financial aid granted from the Ministry of Education.

Publ. Seto Mar. Biol. Lab., VIII (1), 1960. (Article 6) 
sinistral or dextral direction. Usually eggs are arranged irregularly within the gelatinous layer, but rarely they may be in a more or less regular arrangement (Fig. 2, C). As RASMUSSEN (1951) describes the eggs of Stiliger (Stiliger) niger LEмснE, a form allied to the present species, are placed in regular spirals within the egg-mass in the form of cylindrical coil as in many opisthobranchs, especially ascoglossid species, but the regular arrangement of eggs found in the present species seems rather strange. The egg-capsule is round or oval in outline, and 100 to $150 \mu$ in diameter in larger ones. A single ovum is contained in each capsule. Ova vary from 65 to $100 \mu$ in diameter, the size differs from specimen to specimen.

Early development: The observations were made on an egg-mass laid in a glass-vessel on January 10, 1958 when the room temperature was $15^{\circ} \mathrm{C}$. The

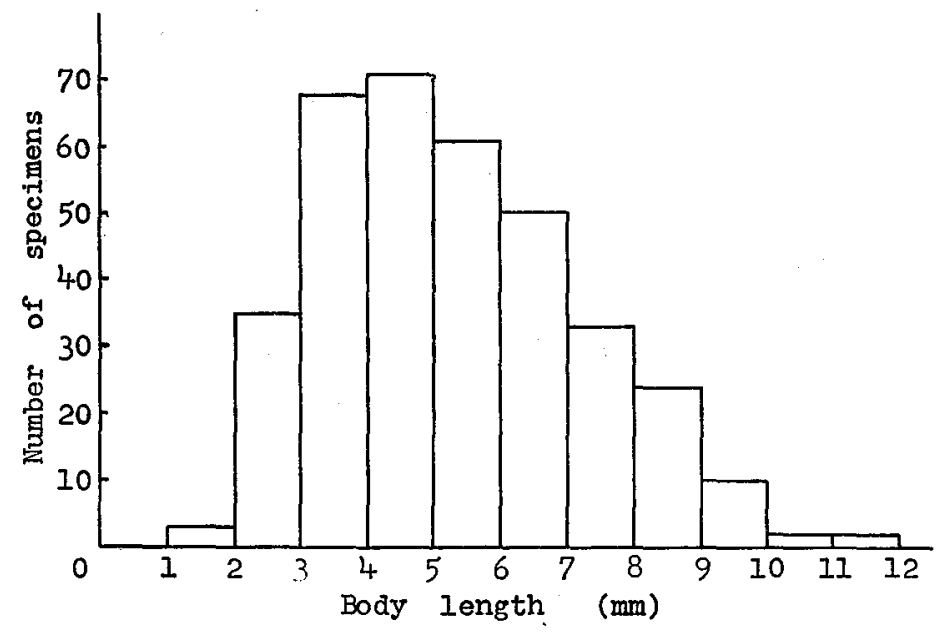

Fig. 1. Stiliger (Stiliger) boodleae BABA.

Graph showing the variation of body length in 359 mature individuals collected at Seto on January 5, 1958.

rotatory movement of embryos within the capsule began on the third day and the embryos passed into young veligers on the next day; at this time the larval kidney and other visceral organs were seen pigmented black, but the shell was not yet distinct. The shell appeared on the sixth day. Thus, it took about seven days from the spawning to the hatching out of the first veliger at the room temperature of $17^{\circ}-20^{\circ} \mathrm{C}$.

Veligers: Newly hatched veligers (Fig. 3, B and C) assume the typical shape of those in Nudibranchia. The shell (Fig. 3, F and G) is sinistral; it is clear, colourless, devoid of any sculptures, and measures 110 to $120 \mu$ long by $80 \mu$ broad. The operculum (Fig. 3, H) is circular or sometimes slightly elongated, and shows 
signs of a dextral-spiral line. The velum is well-developed with strong marginal cilia ; the subvelum is also well-marked; both of these structures are dotted thickly with large refracting granules on their margin. The foot, which has a dense cover of short cilia, is very characteristic in having three to four pairs of large cells with slight yellowish hue, of which one or two are especially large. The ciliated mouth-slit has black pigments on the upper lip. The oesophagus is also pigmented in black on the dorsal wall; it takes a $Z$-shaped course with two sharp bands at about the middle (Fig. 3, C and D), this is probably formed by the contraction of the refractile muscles. The stomach is characterized by being divided into two parts, the first and the second parts; in these are seen the food

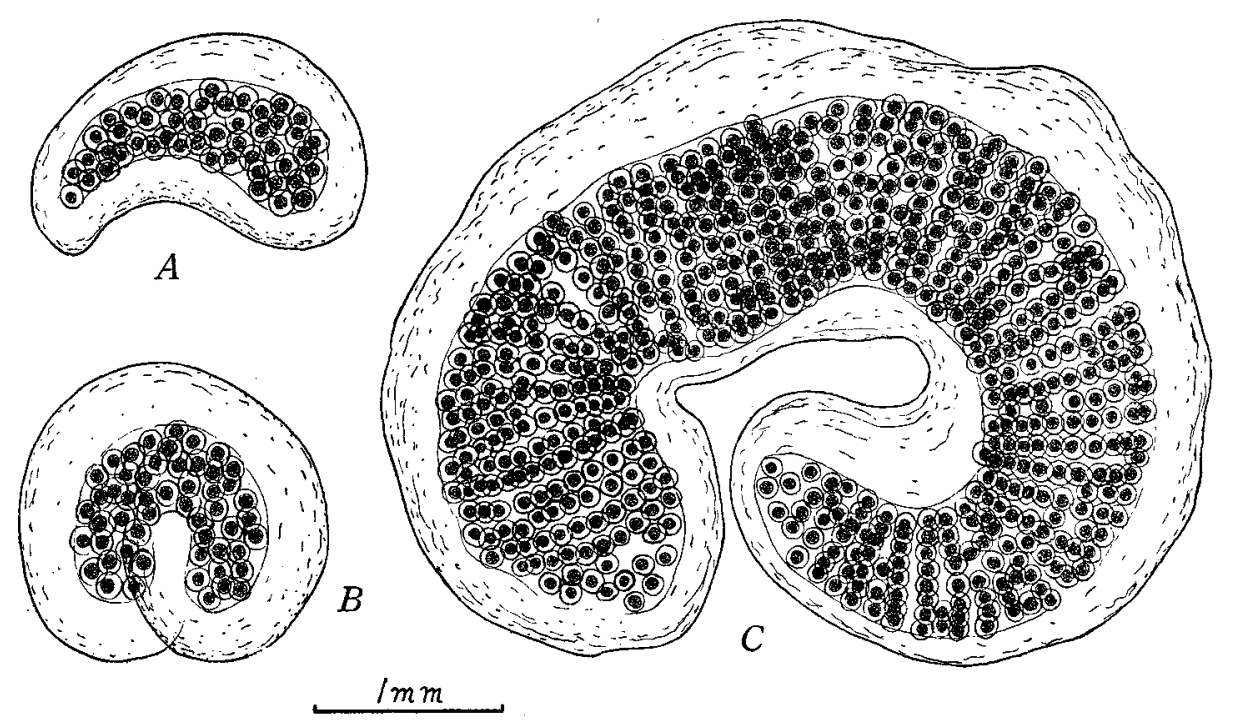

Fig. 2. Stiliger (Stiliger) boodleae BABA.

A, B. Small egg-masses from smaller parent less than $3 \mathrm{~mm}$.

C. Large egg-mass, enclosing spirals of egg-filaments.

particles rotating by the ciliary movement of the stomach epidermis. There are two liver-lobes. The left lobe is connected with the first part of the stomach, yellowish in colour, and appears to consist of several large cells with refracting granules in each of them. The right lobe is smaller than the left, quite colourless, and has a connection with the second part of the stomach.

It was not clarified when the veligers underwent metamorphosis. However, several days after the hatch, a specimen was found passing into the bottom life (Fig. 3, E) ; during this change the larval shell was cast off, and the velar organs became greatly reduced in size. 

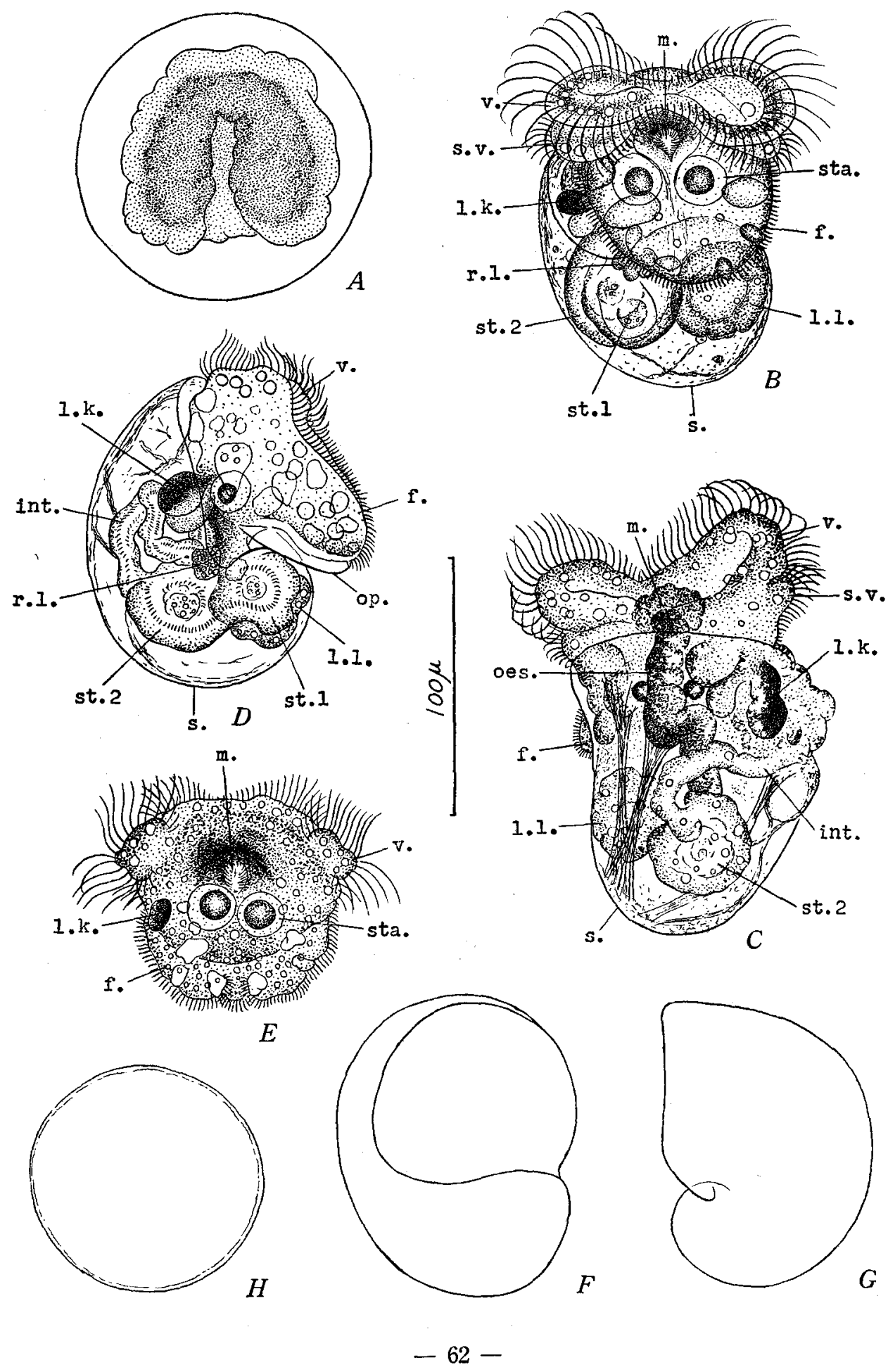


\section{Elysia (Elysia) hamatanii BABA}

(Figs. 4-5)

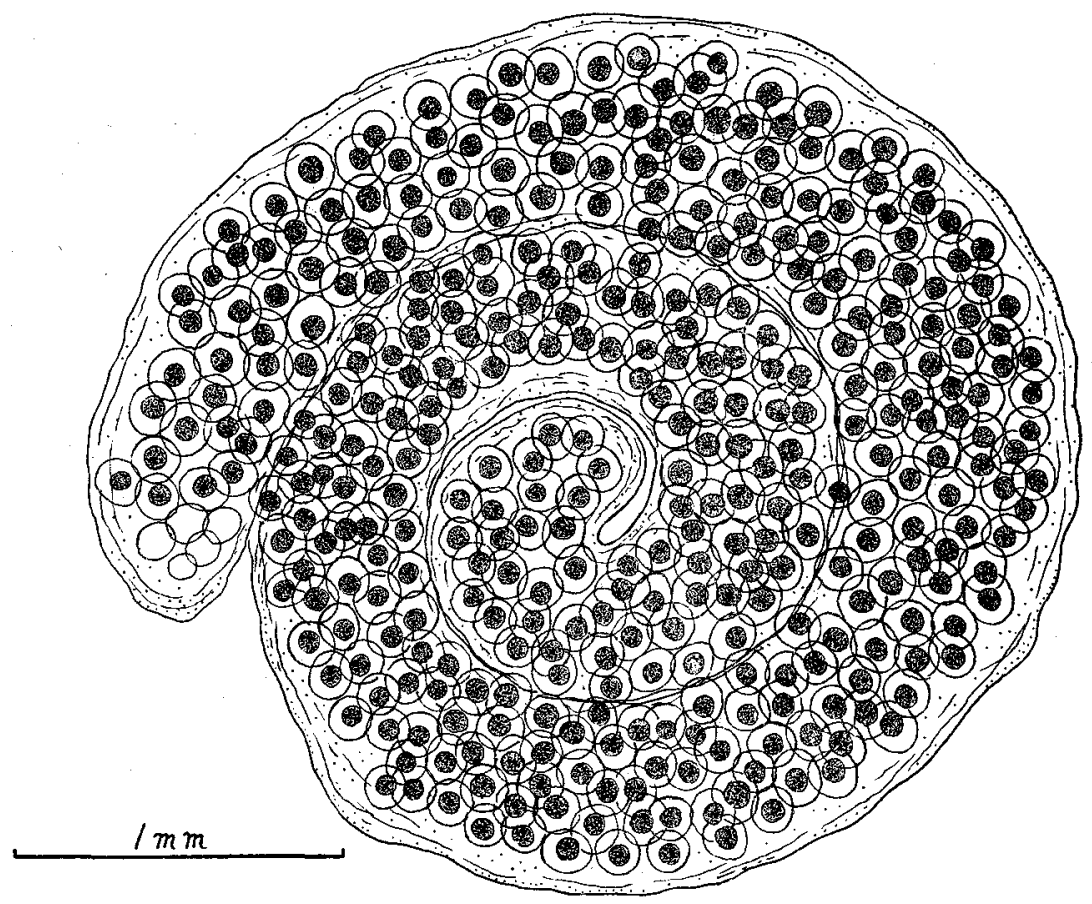

Fig. 4. Elysia (Elysia) hamatanii BABA. Newly laid egg-mass.

The animals are about $10 \mathrm{~mm}$ in length and found very commonly in shallow tide-pools in the high water region of the vicinity of Seto Marine Biological Laboratory during the months from September to February. The egg-laying can be observed easily in the glass-vessel in the laboratory during the period of their

Fig. 3. Stiliger (Stiliger) boodleae BABA.

A. Gastrulation observed in the day of spawning.

B. Newly hatched veliger, from the ventral side.

C. The same, from the dorsal side. Oesophagus curved sharply at the middle is shown clearly.

D. Several days old veliger, from the right side.

E. Veliger in metamorphosis. Shell is cast off and velar organs are degenerated.

F. Larval shell, from the ventral side.

G. The same, from the apex.

H. Operculum.

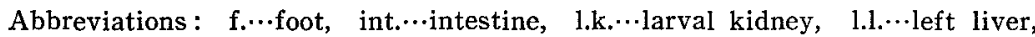
m. $\cdots$ mouth, oes. $\cdots$ oesophagus, op. $\cdots$ operculum, r.l. $\cdots$ right liver, s. $\cdots$ shell,

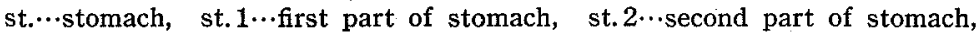
sta...statocyst, s.v...subvelum, v...velum. 
appearance. The egg-masses (Fig. 4) are in the form of a spiral ribbon wound sinistrally in $1 \frac{1}{4}$ to $2 \frac{1}{2}$ convolutions. The whole spiral is slightly yellowish in colour and measures 2 to $3 \mathrm{~mm}$ in diameter. There is a single ovum in each egg-capsule (Fig. 5, A) which is 115 to $140 \mu$ in diameter, while the diameter of ova is about $68 \mu$ on an average.
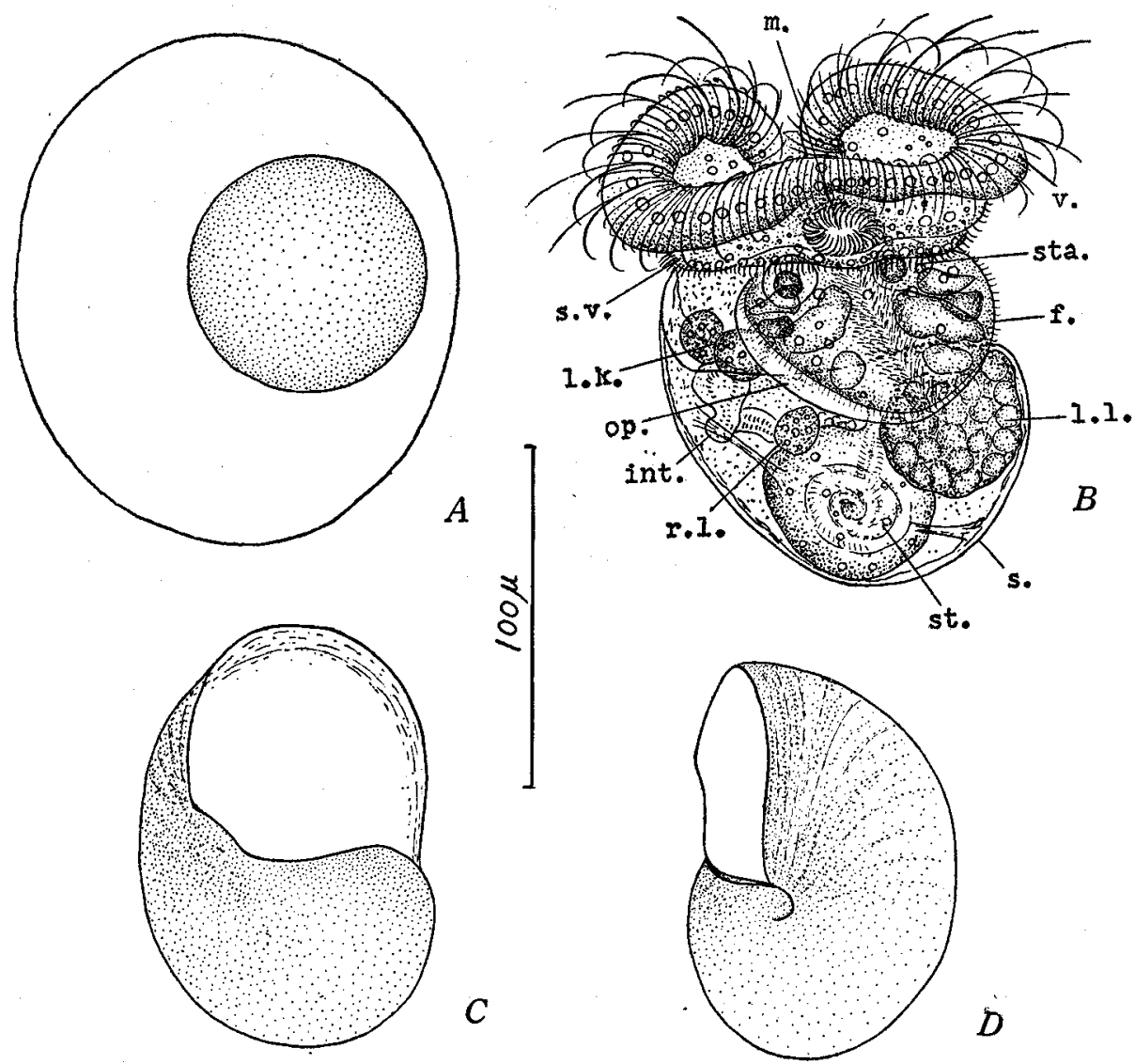

D

Fig. 5. Elysia (Elysia) hamatanii BABA.

A. Ovum in the capsule.

B. Newly hatched veliger, from the ventral side.

C. Larval shell, from the ventral side.

D. The same, from the apex.

(For abbreviations see Fig. 3.)

Early development: The following observations were made on the egg-mass laid in the laboratory on February 21, 1958 when the room temperature was $18^{\circ}-22^{\circ} \mathrm{C}$ and kept there under $15^{\circ}-25^{\circ} \mathrm{C}$. The slight rotatory motion of embryos in the capsule commenced on the second day of the development and embryos attained the earliest stage of veliger on the third day when statocysts were 
discernible in the veliger's body, but the distinct formation of eyes was not yet completed. Veligers stopped the rotatory movement on the fifth day and they were seen escaping from the capsules on the next day.

Veligers: The newly hatched veligers (Fig. 5, B) attain about $130 \mu$ in length and they are nearly colourless. The shell (Fig. 5, C and D) is sinistral, clear and colourless and has closely set sculptures each consisting of small dots, these sculptures are particularly distinct on the underside of the shell near the aperture. The aperture is large, 57 to $65 \mu$ in diameter, and occupies about one half of the whole frontal projection of the shell. The initial whirl of the shell is rather large. The whole shell is 100 to $125 \%$ in the largest diameter, the operculum is circular and has a dextral-spiral line. The velum and subvelum are ciliated as usual. The velum is well-developed and has a row of large refracting granules along the edge. The foot is covered by short cilia all over the surface, especially the median part stretching from the mouth to the tip of the foot bears a strong ciliation. The tissue of the foot contains three to four pairs of large spindle cells, one pair of which is yellowish in colour. The mouth is rather large, ciliated, and unpigmented. The stomach is constituted of a single chamber and provided with two liver-lobes, the left one of which is yellowish and consists of large cells, the right one is much smaller than the left. Two roundish organs, presumably the larval kidneys, are present just near the anus; they are colourless, but contain several refracting granules in their lumen.

\section{Gymnodoris bicolor (ALDER and HANCOCK)}

(Figs. 6-7)

The animals of this species are not rare on the shore around near Seto Marine Biological Laboratory, being found under loose stones. A $10 \mathrm{~mm}$ long individual, brought to the laboratory from the shore of Ezura in the vicinity on January 5, 1958 , was found spawning in the early morning of January 12 when the room temperature was about $18^{\circ} \mathrm{C}$. The spawn (Fig. 6, A) is 2.5 by $6.5 \mathrm{~mm}$ in extent and slightly yellowish in colour. It consists of a flat band (Fig. 6, B) coiled sinistrally in $2 \frac{1}{4}$ turns; the total number of eggs within this egg-mass will amount to 3000 or more. Sometimes the egg-mass may be coiled dextrally. The diameter of ova is $68 \mu$ on an average and that of egg-capsules is about 100 by $140 \mu$ (Fig. 3, C).

Early development: The observed egg-mass was kept at the room temperature of $16^{\circ}-20^{\circ} \mathrm{C}$. It was on the third day of the development that embryos began the rotatory movement. On the fourth day, they assumed the earliest stage of veliger, which was marked by the appearance of statocysts. Veligers escaped from the capsules on the seventh day and entered the free swimming life.

Veligers: The body of veligers (Fig. 7, A-C) is transparent, but faintly 

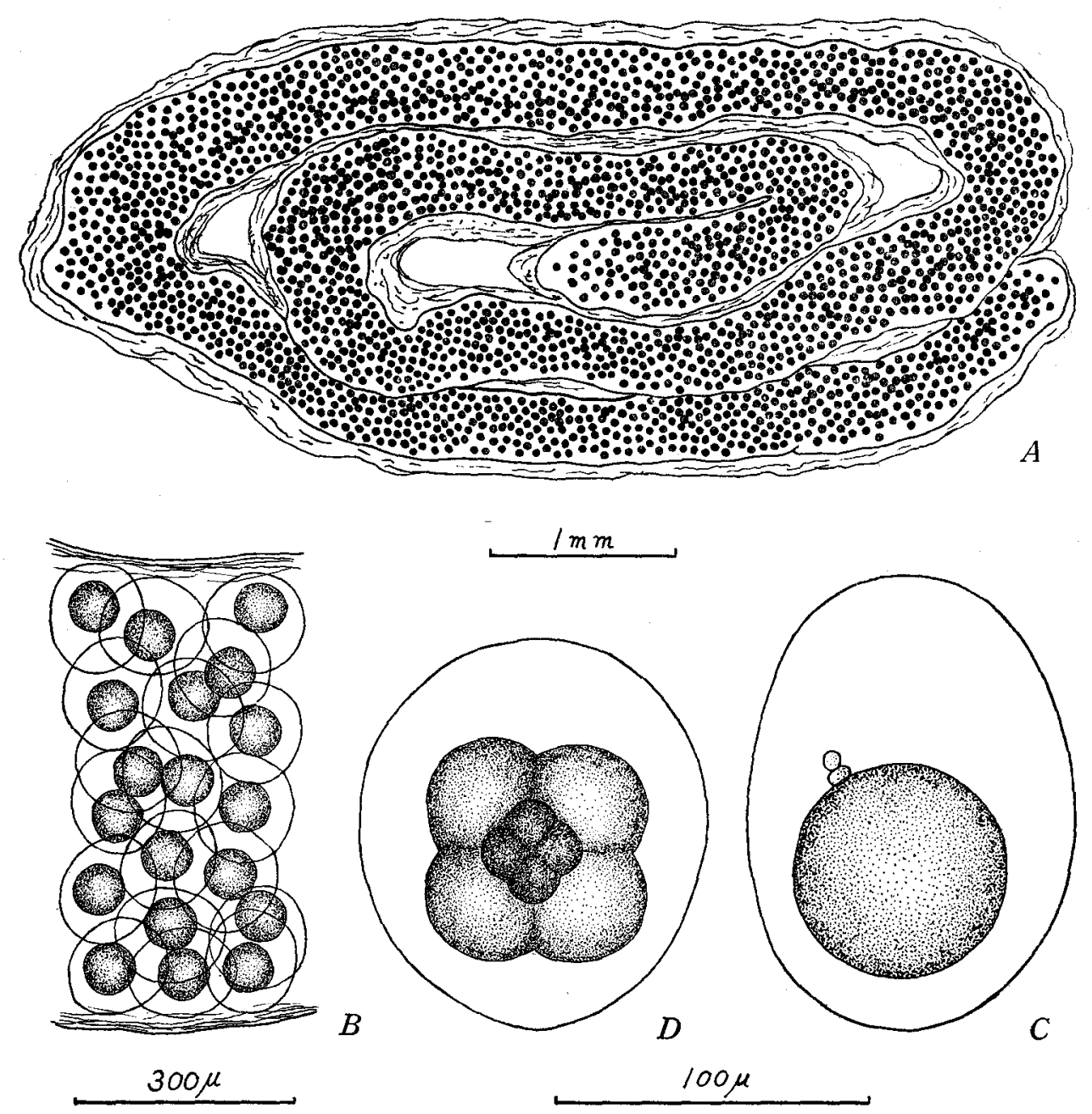

Fig. 6. Gymnodoris bicolor (ALDER and HANCOCK).

A. Newly laid egg-mass.

B. A part of the egg-ribbon.

C. Ovum in the capsule.

D. Eight-cell stage several hours after the spawning.

yellowish. It is very interesting that both dextral and sinistral shells occur in this species (Fig. 7, D-F). The shell is 100 to $115 \mu$ in width. It is colourless and furnished with a kind of fine regular sculptures consisting of small dots. The initial whirl of the shell is very small. The aperture is very large, occupying more than a half of the whole frontal projection of the shell. The velum is rather small and has a row of refracting granules along the margin; the subvelum 
is defined, but not so remarkable. There are no eyes, although statocysts are well marked. The foot contains several pairs of large cells in the tissue, one or two pairs of them are especially large, spindle shaped and yellowish in colour. The mouth is rather small. The stomach is single chambered and with two liver-lobes,

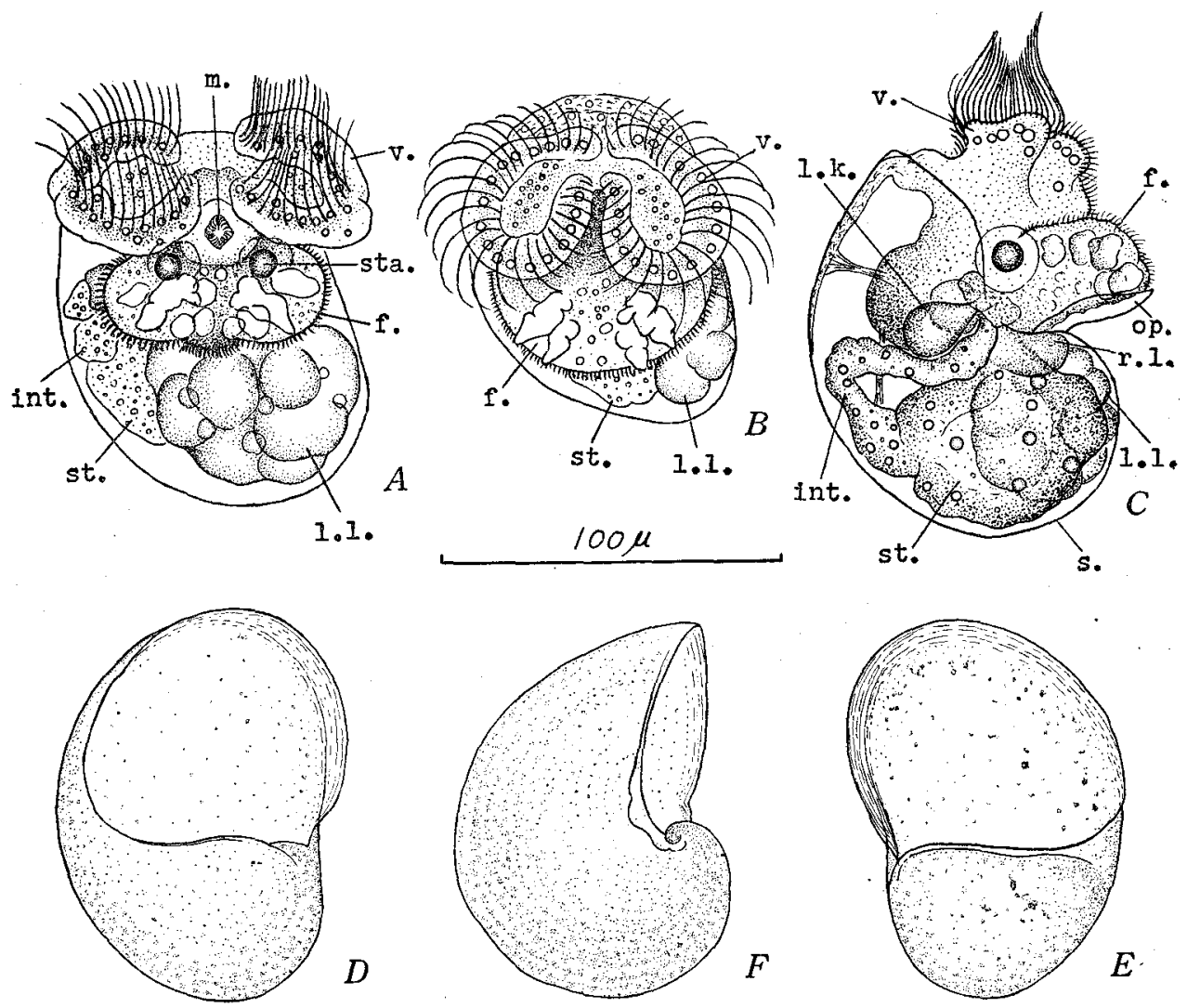

Fig. 7. Gymnodoris bicolor (ALDER and HANCOCK).

A. Veliger in the capsule, from the ventral side; all larval organs are nearly completely formed.

B. The same, frontal view.

C. Newly hatched veliger, from the right side.

D. Sinistral larval shell, from the ventral side.

E. Dextral larval shell, from the ventral side.

F. The same, from the apex.

(For abbreviations see Fig. 3.)

the left liver is larger, yellowish in colour and constituted of several large cells, while the right one is smaller and colourless. The larval kidney is present just above the anus, it is quite colourless. 


\section{Catriona bicolor (BERGH)}

(Fig. 8)

The animals are found very commonly on the shore of Tannowa on the south-eastern coast of Osaka Bay and spawn most frequently during the months from March to April. Mature specimens are 15 to $25 \mathrm{~mm}$ in length. A spawn was got in the laboratory in the morning of March 11, 1958 when the room temperature was $9^{\circ} \mathrm{C}$. It is a ribbon-shaped egg-mass (Fig. 8, A) coiled sinistrally in 3 cylindrical convolutions. The ribbon itself is $40 \mathrm{~mm}$ long when stretched and $2 \mathrm{~mm}$ wide. It is milky white in colour and fastened to the substratum by its proximal edge. A single ovum is contained in each egg-capsule. The diameter of egg-capsules is 130 to $190 \mu$ and that of ova is 85 to $120 \mu$ (Fig. 8, B).

Early development: Embryos attained the nearly completed veliger stage in four to seven days after the spawning and hatching out of larvae from the egg-mass took place in eight to eleven days. The room temperature fluctuated from $9^{\circ}-24^{\circ} \mathrm{C}$ during the observations.

Veligers: Newly hatched veligers (Fig. 8, C-E) are transparent and quite colourless. Most parts of visceral organs are held in the anterior (near the aperture) half of the shell cavity. The shell (Fig. 8, F-H) is sinistral, elongated ovoid in shape and 240 to $270 \mu$ in long diameter. It is colourless and transparent, although it has a kind of sculptures consisting of minute dots. The aperture is rather small, much smaller than a half of the frontal projection of the shell. There is a distinct striation begining at the inner upper angle of the aperture and extending along the columella. The operculum (Fig. 8, I) is semicircular in outline and quite devoid of any sculptures or lines. The velum of veligers is comperatively small, the subvelum is well defined. The foot is also small, and devoid of large cells in the tissue, which are found very distinctly in the preceding species. The oesophagus is short and straight. The stomach and the intestine contain many refracting granules, the latter being short and nearly straight. The right liver is smaller than the left as usual, but the left one is quite colourless and contains a number of refracting granules. The larval kidney is a roundish colourless organ and also contains several refracting granules.

Fig. 8. Catriona bicolor (BERGH).

A. Newly laid egg-mass.

B. Ovum in the capsule.

C. Newly hatched veliger, from the ventral side.

D. The same, from the left side.

E. The same, from the front.

F. Larval shell, from the ventral side.

G. The same, from the under side.

H. The same, from the apex.

I . Operculum.

(For abbreviations see Fig. 3.) 


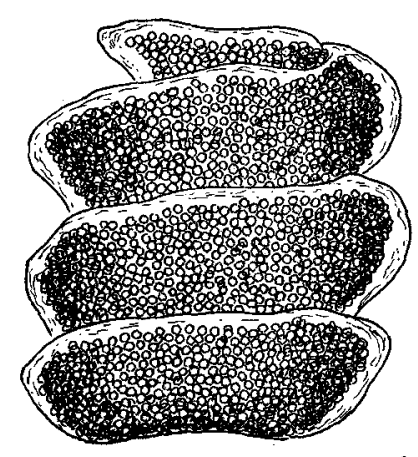

A
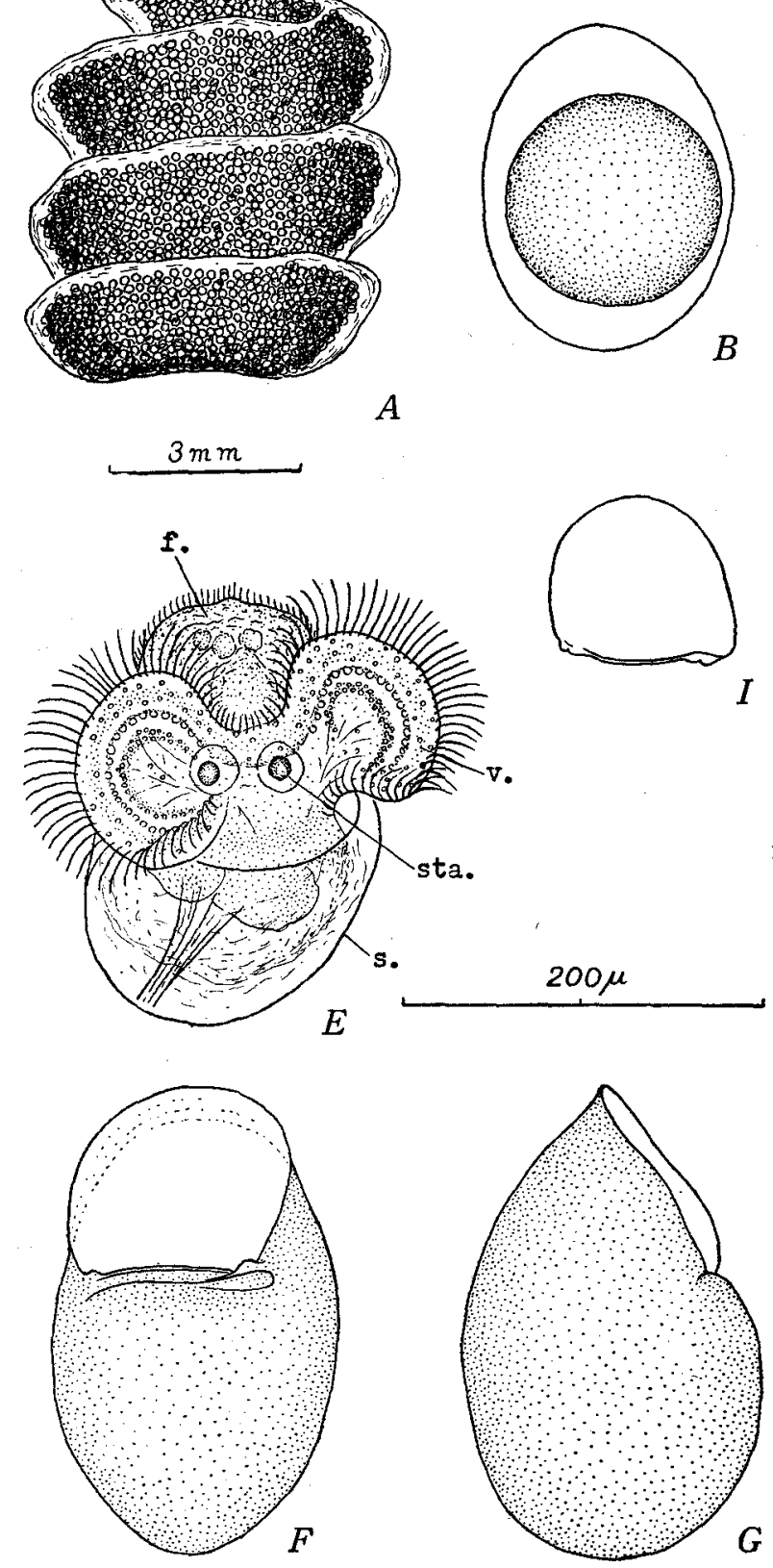
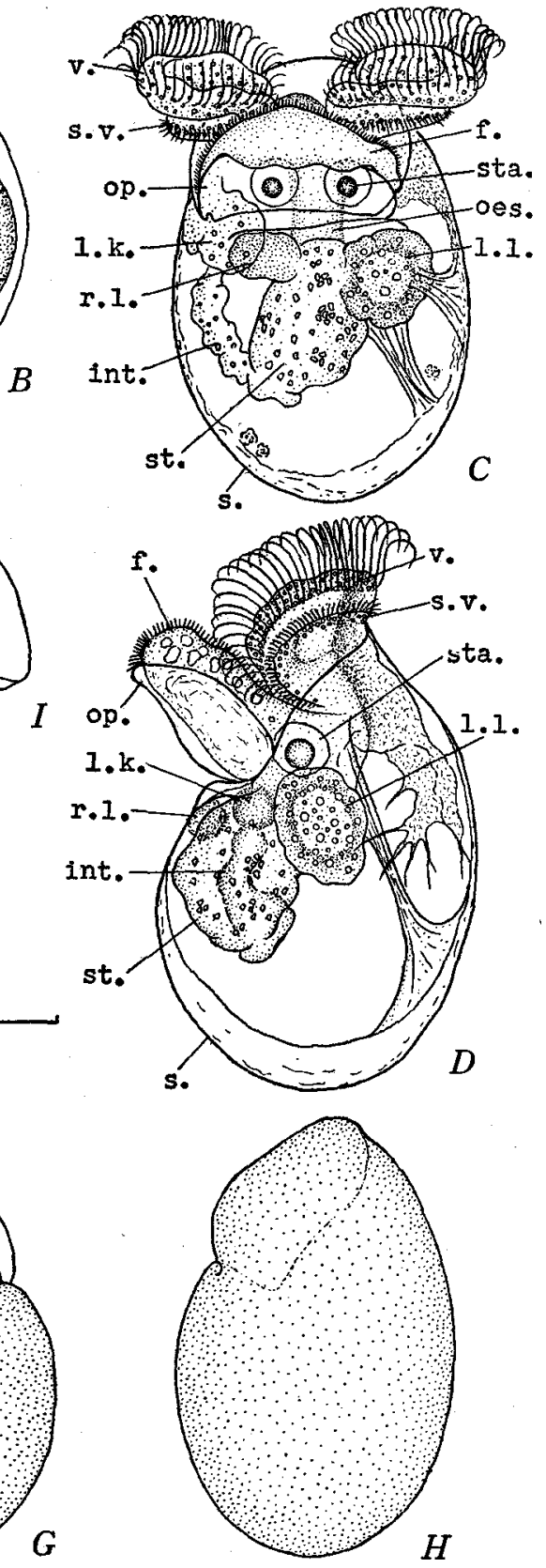


\section{LITERATURE CITED}

BABA, K. and HAMATANI, I. 1954. Observations on the spawning habits of some of the Japanese Opisthobranchia (I). Publ. Seto Mar. Biol. Lab., Vol. 2, No. 2.

Baba, K., Hamatani, I. and Hisai, K. 1956. Observations on the spawning habits of some of the Japanese Opisthobranchia (II). Ibid., Vol. 5, No. 2.

LEMCHE, H. 1935. On some nudibranchiate gastropods from the Northern Atlantic. Vidensk. Medd. fra Dansk naturh. Foren., Bd. 99.

OstergaARD, J. M. 1950. Spawning and development of some Hawaiian marine gastropods. Pacific Science, Vol. 4, No. 2.

RASMUSSEN, E. 1944. Faunistic and biological notes on marine invertebrates I. Vidensk. Medd. fra Dansk naturh. Foren., Bd. 107.

1951. Faunistic and biological notes on marine invertebrates II. Ibid., Bd. 113.

Thorson, G. 1940. Studies on the egg masses and larval development of Gastropoda from the Iranian Gulf. Danish Sci. Invest. Iran, Pt. 2.

1946. Reproduction and larval development of Danish marine bottom invertebrates. Medd. Kommiss. Danmarks Fisk. Havunders., Plankton, Vol. 4, No. 1. 